\title{
The Katanga Reparation Order at the International Criminal Court: Developing the Emerging Reparation Practice of the Court
}

Juan-Pablo Perez-Leon-Acevedo

Post-Doctoral Fellow, PluriCourts, Faculty of Law, University of Oslo, Norway

CONTACT j.p.p.l.acevedo@jus.uio.no

Article funded by the Research Council of Norway-Project Number 223274-PluriCourts.

KEYWORDS International Criminal Court; Germain Katanga; Reparations; Victims

\section{Introduction}

On 24 March 2017, Trial Chamber II (T.Ch-II) of the International Criminal Court (ICC) rendered its reparation order against Germain Katanga, a former alleged leader of the rebel group known as Force de Résistance Patriotique en Ituri (FRPI). ${ }^{1}$ Individual compensation (250 USD) and collective awards (measures that support housing, income-generating activities, education and psychological well-being) were granted. This reparation order follows the conviction and sentence of Katanga (7 March 2014 and 23 May 2014 respectively). The award against Katanga orders reparations in favour of victims of the crimes for which he was convicted, namely, crimes against humanity (murder) and war crimes (murder, attacking a civilian population, destruction of property and pillaging) committed on 24 February 2003 during the attack on the village of Bogoro, in the Ituri district of the Democratic Republic of Congo (DRC). The Katanga reparation order constitutes one of the

\footnotetext{
${ }^{1}$ Katanga (ICC-01/04-01/07-3728), Ordonnance de réparation en vertu de l'article 75 du Statut, T.Ch-II (24 March 2017).
} 
first major reparation decisions in the ICC's emerging reparation practice-preceded by the reparation decision of Trial Chamber I (T.Ch-I) in Lubanga, ${ }^{2}$ partially amended by the Appeal

Chamber (A.Ch.). ${ }^{3}$ Generally speaking, the Katanga reparation order builds up on principles, procedural and substantive law of reparations developed in Lubanga, but it fleshes out certain (untouched) aspects of the ICC reparation system. This includes that in Katanga an ICC Chamber quantified harm and granted individual compensations for the first time. The Katanga reparation order arguably continues the efforts of the ICC Chambers to develop the ICC reparation system and handle related challenges.

Accordingly, this legal development article examines key issues discussed in the Katanga reparation order. After an overview of the ICC reparation system, the Katanga reparation order is discussed under these categories: reparation principles and elements of reparation order; definition of victims and evidentiary criteria; types of reparation; modalities of reparation; and reparation implementation.

\section{The ICC Reparation System}

The ICC introduced the first reparation system among international criminal tribunals (ICTs) and is grounded on articles 75 (reparations to victims) and 79 (Trust Fund for Victims (TFV)) of the ICC Statute as complemented by Rules of Procedure and Evidence and TFV Regulations. During the ICC Statute negotiation and drafting, there was a strong support to include an ICC reparation system and rectify the lack thereof at ICTs. ${ }^{4}$ The ICC adds an

\footnotetext{
${ }^{2}$ Lubanga (ICC-01/04-01/06-2904), Decision Establishing the Principles and Procedures to be Applied to Reparations, T.Ch-I (7 August 2012).

${ }^{3}$ Lubanga (ICC-01/04-01/06-3129-AnxA), Order for Reparations (amended), A.Ch (3 March 2015).

${ }^{4}$ Christopher Muttukumaru, 'Reparation to Victim' in Roy Lee (ed), The International Criminal Court-The Making of the Rome Statute (Kluwer 1999) 262-270.
} 
important dimension of restorative/remedial justice to international criminal proceedings, ${ }^{5}$ because it places victims as reparation claimants at the centre stage to redress their harm. ${ }^{6}$ Previous ICTs were almost exclusively driven by retributive/deterrent justice. ${ }^{7}$ The ICC reparation system pursues that the convicted redresses the harm inflicted on victims, ${ }^{8}$ i.e., remedial justice, ${ }^{9}$ and relief of victim suffering and reconciliation, ${ }^{10}$ i.e., restorative and transitional justice. ${ }^{11}$ Whether these goals may be satisfied is yet to be seen. However, the Katanga reparation order may (potentially) catalyse reparation/reconciliation. Moreover, a successful ICC reparation system is linked to the overall success of the ICC. ${ }^{12}$

As the Katanga reparation order shows, there is a synergy between retributive and restorative justice systems at the ICC: ICC reparations depend on and complement ICC convictions to pursue/achieve holistic justice for victims. Also, this may cause tensions even beyond the ICC. As transitional justice national experiences demonstrate, responsible states may face dilemmas concerning reparation/reconciliation vis-à-vis retribution/deterrence. ${ }^{13}$

At the ICC reparation system, victims of mass atrocities can exercise their right to reparations, which is a well-established right in international human rights treaties. ${ }^{14}$ The ICC Chambers have especially relied on instruments such as the UN Reparation Principles ${ }^{15}$ and case-law of human rights courts. ${ }^{16}$ Not the mechanical use of these external sources but their application as adapted to the particular circumstances of the ICC reparation system is sound. The ICC practice shows related ongoing efforts. Thus, the ICC reparation system implements

\footnotetext{
${ }^{5}$ Eva Dwertmann, The Reparation System of the International Criminal Court-Its Implementation, Possibilities and Limitations (Martinus Nijhoff 2010) 37-44.

${ }^{6}$ Howard Zehr, Changing Lenses-A New Focus for Crime and Justice, (1st edn, Herald Press 1990) 212-214.

${ }^{7}$ Antonio Cassese, International Criminal Law (2nd edn, OUP 2008) 366-377.

${ }^{8}$ Lubanga (n 3) para 2; Katanga (n 1) para 16.

${ }^{9}$ Dinah Shelton, Remedies in International Human Rights Law (3rd edn, OUP 2015) 19-21.

${ }^{10}$ Lubanga (n 2) para 179; Katanga (n 1) para 267.

${ }^{11}$ Shelton (n 9) 22-27.

${ }^{12}$ Katanga (n 1) para 14.

${ }^{13}$ See Ruti Teitel (ed), Globalizing Transitional Justice (OUP 2016).

${ }^{14}$ Lubanga (n 2) para 185.

${ }^{15}$ Basic Principles and Guidelines on the Right to a Remedy and Reparation for Victims of Gross Violations of International Human Rights Law and Serious Violations of International Humanitarian Law, UN General Assembly Resolution 60/147 (16 December 2005).

${ }^{16}$ Lubanga (n 2) para 186; Katanga (n 1) paras 230-231.
} 
the right to reparations in international criminal law and the principle of the convicted's accountability for the harm inflicted. ${ }^{17}$ (International) practice indicates that victims can obtain reparations from the convicted at (international) criminal courts. ${ }^{18}$

Under the ICC Statute (article 75(2)), reparation orders rendered by the ICC Chambers may only be made against the convicted, ${ }^{19}$ not against states unlike at human rights courts. Victims can claim and receive individual and/or collective reparations consisting in restitution, compensation, rehabilitation and/or symbolic measures. Victims do not need to participate in ICC trials to receive reparations. ${ }^{20}$ However, victims as reparation claimants are parties to post-conviction reparation proceedings. ${ }^{21}$ Thus, they hold procedural rights such as oral and written participation; presentation of evidence, witnesses and experts; right to appeal reparation orders; and legal representation.

The TFV, set up to benefit victims of ICC-jurisdiction crimes, ${ }^{22}$ is an important component of the ICC reparation system. Established by the Assembly of States Parties to the ICC Statute (ICC-ASP), ${ }^{23}$ the TFV has two mandates: ${ }^{24}$ a reparation mandate to ensure funds when the ICC grants article $75(2)$ reparation orders $;^{25}$ and an assistance function. Whereas under the TFV reparation-mandate the ICC may instruct the TFV to use resources deposited with it to implement reparation awards, in its assistance mandate the TFV uses voluntary contributions to aid victims from ICC situations.

\footnotetext{
${ }^{17}$ Liesbeth Zegveld, 'Victims' Reparations Claims and International Criminal Courts' (2010) 8 JICJ 79, 85; Christine Evans, The Right to Reparation in International Law for Victims of Armed Conflict (CUP 2012) 122128.

${ }^{18}$ Jean-Marie Henckaerts and Louise Doswald-Beck, Customary International Humanitarian Law, vol. 1 (CUP/ICRC 2005) 554-555.

${ }^{19}$ Dwertmann (n 5) 68-71.

${ }^{20}$ Brianne McGonigle-Leyh, Procedural Justice?-Victim Participation in International Criminal Proceedings (Intersentia 2011) 239.

${ }^{21}$ Salvatore Zappalà, 'The Rights of Victims v. the Rights of the Accused' (2010) 8 JICJ 137, 154.

${ }^{22}$ ICC Statute art 79(1).

${ }^{23}$ Establishment of a Fund for the Benefit of Victims of Crimes within the Jurisdiction of the Court, and of the families of such Victims, Resolution ICC-ASP/1/Res.6, 9 September 2002, 160-179.

${ }^{24} \mathrm{TFV}$ regulation 50 (a)(i).

${ }^{25}$ Situation in the DRC (ICC-01/04-492), Decision on the Notification of the Board of Directors of the Trust Fund for Victims in accordance with Regulation 50 of the Regulations of the Trust Fund, Pre-Trial Chamber I, 7 (11 April 2008).
} 


\section{Principles of Reparations and Elements of Reparation Orders}

As for judicial determination of ICC reparation principles, ${ }^{26} \mathrm{~T}$.Ch II found that the principles established by the A.Ch in Lubanga would be applicable in Katanga but subject to modifications contained in the reparation award. ${ }^{27}$ Among the number of reparation principles determined by the A.Ch, T.Ch-II explicitly mentioned a few of them, including: humanity and dignity; equal treatment; inclusiveness; safety, physical and psychological well-being and privacy of victims; and non-discrimination. ${ }^{28}$ The ICC reparation principles have been mainly extrapolated from international human rights law sources rather than comparative law examination. Such approach benefits from the robust development of reparations for victims of gross atrocities in international human rights law.

In turn, following the A.Ch's criteria, ${ }^{29}$ T.Ch II in Katanga determined that reparation orders under article 75 must: be against the convicted; establish and inform the convicted of his/her liability; indicate the type(s) of reparations (individual/collective); define the harm inflicted on direct and indirect victims as a result of the crimes for which the accused was convicted and determine modalities of reparations (compensation, etc.); and identify the victims who can benefit from awards or set out eligibility criteria. ${ }^{30}$ Unlike Lubanga, T.Ch-II in Katanga examined the 341 individual reparation applications to meet the said five criteria. $^{31}$

That the Katanga reparation order has largely adopted the reparation principles and elements of reparation orders determined by the A.Ch is welcome because such approach is necessary for consistency or coherence of the ICC's reparation practice. This benefits ICC

\footnotetext{
${ }^{26}$ ICC Statute art 75(1).

${ }^{27}$ Katanga (n 1) para 30.

${ }^{28}$ Ibid.

${ }^{29}$ Lubanga (ICC-01/04-01/06-3129), Judgment on the appeals against the "Decision establishing the principles and procedures to be applied to reparations" of 7 August 2012, A.Ch, para 1 (3 March 2015).

${ }^{30}$ Katanga (n 1) para 31.

${ }^{31}$ Ibid para 33.
} 
reparation parties since consistent application of reparation principles and elements of reparation orders enhance certainty and fairness. ${ }^{32}$

However, due to the general nature of reparation principles and elements of reparation orders, T.Ch-II should have in advance indicated the principles and elements it would consider. The accused's presumption of innocence would not have been affected as a reparation order is rendered post-conviction. In Lubanga, the ICC-ASP actually criticized the delay in establishing reparation principles. ${ }^{33}$ Such procrastination may neglect reparation claimants and limit opportunities to progressively keep victims and defendants informed of coming reparation proceedings.

Furthermore, in Katanga (like in Lubanga), T.Ch-II did not further elaborate on principles involving addressees other than the accused. Considering financial and logistical constraints faced by the ICC reparation system, T.Ch-II could have construed non-binding principles and award criteria which address other important actors in armed conflicts such as states, corporations, armed groups and the international community. ${ }^{34}$

\section{Definition of Victims and Evidentiary Criteria}

Rule 85(a) defines 'victims' as follows: 'natural persons who have suffered harm as a result of the commission of any crime within the jurisdiction of the Court'. T.Ch-II in Katanga appropriately adapted this general definition, which applies to victim protection, participation and reparations, into the specific realm of reparations. T.Ch-II found that victims for reparation purposes are those who suffered harm as a result of a crime under the ICC's jurisdiction provided that these crimes correspond to those for which the accused was

\footnotetext{
${ }^{32}$ Dwertmann (n 5) 46.

${ }^{33}$ ICC-ASP/10/Res.3, 20 December 2011.

${ }^{34}$ Dwertmann (n 5) 51-61.
} 
convicted. ${ }^{35}$ Although harm must have been suffered personally, harm does not have to be direct: reparations can be provided to direct and indirect victims. ${ }^{36}$

Concerning evidentiary criteria, claimants shoulder the burden of proof of both their identity and the causal link between the harm inflicted and the crime(s) for which the person was convicted. ${ }^{37}$ Crucially, T.Ch-II in Katanga was mindful of problems of access to evidence experienced by victims as there was destruction or inability of evidentiary documents and a number of years (14) elapsed since the events occurred. ${ }^{38}$ This is important to avoid unrealistically demanding evidentiary standards. ${ }^{39}$ By inter alia invoking case-law of the Inter-American Court of Human Rights (IACtHR), the Extraordinary Chambers in the Courts of Cambodia (ECCC) and Lubanga, T.Ch-II found that the standard of 'balance of probabilities' rather than the more demanding standard of 'beyond reasonable doubt' is applicable. ${ }^{40}$ Moreover, by referring to the IACtHR, the German Forced Labour Compensation Programme and the UN Compensation Commission, T.Ch-II concluded that the use of presumptions and indirect evidence to establish certain facts was appropriate in Katanga. ${ }^{41}$ After an individualized analysis of reparation claims, ${ }^{42}$ T.Ch-II found a number of incidents of material, physical and psychological harm as detailed later.

The combination of the above-examined notion of victims and evidentiary criteria underlies the notion and application of 'indirect victims', namely, victims who endured harm as a result of the harm suffered by direct victims. ${ }^{43}$ The ICC case-law has accepted this dimension of victimhood. Adopting IACtHR's practice, in Lubanga, moral harm suffered by parents, i.e., indirect victims, as a consequence of crimes committed against their children,

\footnotetext{
${ }^{35}$ Katanga (n 1) para 37.

${ }^{36}$ Ibid para 39.

${ }^{37}$ Ibid para 45.

${ }^{38}$ Ibid para 47.

${ }^{39}$ Conor McCarthy, Reparations and Victim Support in the International Criminal Court (CUP 2012) 260.

${ }^{40}$ Katanga (n 1) paras 48-50.

${ }^{41}$ Ibid paras 57-61.

${ }^{42}$ Ibid paras 64-180.

${ }^{43}$ Valentina Spiga, 'Indirect Victims' Participation in the Lubanga Trial' (2010) 8 JICJ 183.
} 
i.e., direct victims, was presumed due to their close personal relationship. ${ }^{44}$ Nevertheless, the Katanga reparation order arguably shows more caution when using presumptions and indirect evidence. T.Ch-II correctly highlighted that the IACtHR deals with state responsibility rather than individual criminal liability. ${ }^{45}$ In any event, T.Ch-II used presumptions and indirect evidence as construed by inter alia the IACtHR to find the harm suffered by the reparation claimants. ${ }^{46}$ Indeed, T.Ch-II endorsed the presumption under which parents of victimized children are indirect victims as their psychological harm resulting from the murder of their children is presumed based on the parental link. ${ }^{47}$

\section{Types of Reparations}

T.Ch-II in Katanga highlighted that individual and collective reparations are not mutually exclusive and can be granted cumulatively. ${ }^{48}$ Importantly, unlike Lubanga, T.Ch-II discusses the conceptual scope of both. This fills in a normative gap since the ICC legal instruments provide no notion of individual or collective reparations despite several references to them. Thus, should the beneficiaries of reparation orders be considered as the defining standard, a collective award may address one of the following two general groups: an ethnic, racial, social, political or religious group that pre-existed the crime; or a group that can be identified subsequently to the collective harm out of the crimes for which a person was convicted. ${ }^{49}$

\footnotetext{
${ }^{44}$ Lubanga (n 2) para 195.

${ }^{45}$ Ibid footnote 102.

${ }^{46}$ Katanga (n 1) para 57.

${ }^{47}$ Ibid.

${ }^{48}$ Ibid para 270.

${ }^{49}$ Ibid para 274.
} 
Nevertheless, this 'fragmentation' of victimhood for reparation purposes may potentially lead to tensions and conflicts. ${ }^{50}$

Unlike the collective reparation-oriented approach in Lubanga (especially adopted by the TFV), T.Ch-II in Katanga assessed and granted both individual and collective reparations, relying on inter alia case-law of the IACtHR, the African Commission on Human and People's Rights, and the Court of Justice of the Economic Community of West African States. ${ }^{51}$ T.Ch-II found that collective reparations can help but not substitute individual reparations. ${ }^{52}$ It added that collective reparations avoid stigmatisation, are responsive to common needs and the complexity of harm of different victims as well as promote reconciliation. ${ }^{53}$ In turn, individual reparations prevent victims from feeling excluded or being marginalized, individually recognize victims, and enable victims to recover their autonomy and take their own decisions based on their real needs. ${ }^{54}$ Thus, T.Ch-II considered that collective reparations should focus on victims as much as possible, which is feasible because collective reparations is an open concept and allows a focus on both individual and communitarian benefits. ${ }^{55}$

The Katanga reparation order gives to collective and individual reparations the same importance. T.Ch-II's approach of combining both types of reparations is sound. When it is feasible, necessary and pertinent, granting both collective and individual awards is advisable to make humbly funded programs significant in cases of mass atrocities. ${ }^{56}$ However, the ICC reparation orders should mainly focus on collective awards, without excluding individual awards. At the ICC, collective reparations are in principle more appropriate because of the

\footnotetext{
${ }^{50}$ Dwertmann (n 5) 101.

${ }^{51}$ Katanga (n 1) paras 265-295.

${ }^{52}$ Ibid para 284.

${ }^{53}$ Ibid paras 285, 289.

${ }^{54}$ Ibid para 285.

${ }^{55}$ Ibid para 294.

${ }^{56}$ Lisa Magarrell, Reparations in Theory and Practice (ICTJ 2007) 7.
} 
collective nature of ICC-jurisdiction crimes. ${ }^{57}$ At the ICC, cases mainly concern crimes that directly target specific groups and, indeed, individual victimization stems from attacks against the respective community or group. ${ }^{58}$ This is related to the notion of collective victims. ${ }^{59}$ Also, justice must consider 'the preconditions of reconstructing the rule of law, an aim that has a public, collective dimension' ${ }^{60}$ In scenarios of mass violations, collective reparations would be advisable as they benefit persons who endured human rights abuses as a community or group. ${ }^{61}$ Collective reparations seek to handle identity dimensions of individual abuses, including attacks against communities or urban settlements, targeting of ethnic groups, as well as widespread or systematic gender/sexual violence. ${ }^{62}$ Large-scale commission of international crimes and the interests of justice demand to go beyond individual-focused redress. $^{63}$

Additionally, when a group has suffered harm, institutional reform initiatives, community development projects and symbolic measures may be preferable. ${ }^{64}$ Even if payments are nominal, victims generally cherish long-term impact programmes as 'forward-looking measures that improve the chances of future generationss. ${ }^{65}$

Furthermore, individual reparations are difficult to implement as the convicted individual's financial situation may not permit to, for example, compensate an important number of victims. The effectiveness and efficiency of the ICC reparation system may be severely compromised if the ICC has to allocate its limited resources to handle large numbers of

\footnotetext{
${ }^{57}$ Dwertmann (n 5) 122.

${ }^{58}$ Cherif Bassiouni, 'The Protection of 'Collective Victims' in International Law' in Cherif Bassiouni (ed), International Protection of Victims (Eres 1998) 181, 184; Dwertmann (n 5) 122.

${ }^{59}$ Cherif Bassiouni, 'International Recognition of Victims' Rights' (2006) 6 Human Rights Law Review $203,257$.

${ }^{60}$ Pablo de Greiff, 'Introduction-Repairing the Past Compensation for Victims of Human Rights Violations' in Pablo de Greiff (ed), The Handbook of Reparations (OUP 2006) 1, 14.

${ }^{61}$ Magarrell (n 56) 5.

${ }^{62}$ Juan-Pablo Perez-Leon-Acevedo, Victims' Status at International and Hybrid Criminal Courts (Åbo Akademi 2014) 759 .

${ }^{63}$ Ibid.

${ }^{64}$ Magarrell (n 56) 5-6.

${ }^{65}$ Naomi Roth-Arriaza, 'Reparations, Decisions and Dilemmas' (2004) 27 Hastings International and Comparative Law Review 157, 181.
} 
individual reparation claims. Under certain circumstances, collective awards could be the only option as individual awards would exclude a high number of victims and/or would not be implementable. $^{66}$

However, it is also necessary to provide individual awards. First, international human rights norms and standards are generally expressed in individual terms and, indeed, individual reparations explicitly recognize the status of individual victims as human rights holders. ${ }^{67}$ Under IACtHR case-law and national practice on mass atrocities, individual and collective awards are ordered/provided. ${ }^{68}$ Second, victims may prefer individual over collective awards. ${ }^{69}$ Individuals may even be reluctant to receive collective awards when these neglect or overlook the individual dimension of the crimes. ${ }^{70}$ Finally, collective reparations are not necessarily easier to implement as, inter alia, they may overlap with development programmes and accurate identification of communities for reparation may be challenging. ${ }^{71}$ For example, implementation of ECCC collective/moral reparations has faced several challenges. $^{72}$

\section{Modalities of Reparations}

Regarding modalities of reparations, i.e., restitution, compensation, rehabilitation and symbolic measures, ${ }^{73}$ the Katanga reparation order adopts a more methodological approach than that observed in Lubanga. In Katanga, each type of awards (individual and collective) is

\footnotetext{
${ }^{66}$ Roth-Arriaza (n 65) 185.

${ }^{67}$ Magarrell (n 56) 5.

${ }^{68}$ Plan de Sanchez Massacre v Guatemala, Judgment (Reparations) (29 November 2004) ; Colombian Law 1448 (2011).

${ }^{69}$ E.g., Lubanga.

${ }^{70}$ Magarrell (n 56) 6.

${ }^{71}$ Ibid.

${ }^{72}$ Case 001, Appeal Judgment (3 February 2012).

${ }^{73}$ UN Reparation Principles 19-23; Bassiouni (n 59) 267-275.
} 
examined in relation to modalities of reparations, namely, compensation and others, which was not explicitly done in Lubanga.

Concerning modalities of individual reparations, T.Ch-II focused on compensation. Related to it, T.Ch-II quantified harm. Indeed, unlike Lubanga, Katanga is the first ICC case at which an ICC Chamber conducted a quantitative determination of the harm inflicted on victims. This harm was broken down and quantified in USD as follows: material harm, including damages to houses, businesses, livestock, and fields/harvests (50-3000 USD); physical harm caused by bullet wounds (250 USD); and psychological harm, considering two sub-categories: loss of a close relative (8000 USD) or a distant relative (4000 USD), and harm related to the experience of the attack (2000 USD). ${ }^{74}$

Regarding psychological harm, the Chamber relied on factors identified by the IACtHR, ${ }^{75}$ including: presumption of harm inflicted on a person when (s)he losses closed family members. ${ }^{76}$ However, objective quantification of psychological harm is challenging. ${ }^{77}$ After examining domestic and international systems, T.Ch-II applied Pueblo Bello Massacre figures where the IACtHR rendered lower amounts than in other similar IACtHR cases. ${ }^{78}$ This selection arguably corresponds to the scarcity of resources for reparations and Katanga's indigence.

The total amount of harm inflicted on the Katanga victims was quantified in 3.752 .620 USD and Katanga was found to be individually liable for 1 million USD. ${ }^{79}$ Unlike in Lubanga ${ }^{80}$ T.Ch-II in Katanga examined and granted individual compensation claims (297 out of 341). ${ }^{81}$ However, because of the lack of resources (related to Katanga's indigence),

\footnotetext{
${ }^{74}$ Katanga (n 1) para 239.

${ }^{75}$ Pueblo Bello Massacre v Colombia, Judgment (31 January 2006) paras 254-257; Plan de Sanchez Massacre (n 68) paras 77-89.

${ }^{76}$ Katanga (n 1) para 231.

${ }^{77}$ McCarthy (n 39) 117-118.

${ }^{78}$ Katanga (n 1) paras 230-232.

${ }^{79}$ Ibid paras 239, 264.

${ }^{80}$ Lubanga (n 2) para 289.b.

${ }^{81}$ Katanga (n 1) paras 251-264.
} 
T.Ch-II only granted a symbolic sum of 250 USD to each victim, and recognized that this figure does not fully compensate the harm inflicted but only assists to relieve harm, particularly, help victims become economically autonomous. ${ }^{82}$

This modest outcome prompts to question whether compensation is pertinent and/or possible at the ICC. It has been said that compensation is not necessarily the most appropriate reparation modality even if there are resources because other modalities such as symbolic measures, community development grants and institutional reform may be preferable when a group has suffered harm. ${ }^{83}$ Additionally, rehabilitation and assistance programmes may be better than compensation, especially when the amount of payment is nominal. ${ }^{84}$ However, when feasible, reparation awards should integrate monetary, material and symbolic components rather than rely exclusively or exclude altogether a specific modality of reparation. ${ }^{85}$ An appropriate combination of compensation with other modalities is indeed suggested by UN Reparation Principle 15 when this invokes 'adequate, appropriate and prompt reparation'. In cases of serious abuses such as forced disappearance, arbitrary execution and/or torture, human rights bodies like the ECtHR have inter alia ordered compensation. ${ }^{86}$ The Extraordinary African Chambers (a hybrid criminal court) ${ }^{87}$ and national courts/institutions ${ }^{88}$ have ordered and/or provided compensation concerning international crimes and/or serious human rights violations.

Compared to the average compensatory amounts ordered by other international courts, ${ }^{89}$ the symbolic amount (250 USD) granted by the ICC is quite low and may cause revictimization. This evidences the need for state cooperation as well as coordination and

\footnotetext{
${ }^{82}$ Ibid para 230.

${ }^{83}$ Magarrell (n 56) 5-6.

${ }^{84}$ Roth-Arriaza (n 65) 162.

${ }^{85}$ Magarrell (n 56) 4.

${ }^{86}$ Bazorkina v. Russia App no 69481/01 (ECHR, 11 December 2006) 178-181.

${ }^{87}$ Habré, Arrêt (27 April 2017).

${ }^{88}$ Bassiouni (n 59) 218-239.

${ }^{89}$ See Jo Pasqualucci, The Practice and Procedure of the Inter-American Court of Human Rights (2nd edn, CUP 2013) 229-246.
} 
cooperation between the ICC and other international and national mechanisms. Indeed, the importance of compensation in cases of serious human rights violations has been remarked. ${ }^{90}$

Overall speaking, compensation may play an important function within the ICC reparation system. However, in Katanga, the individual compensatory amount has caused certain frustration and disappointment among victims. ${ }^{91}$ To avoid similar situations, the ICC may subject its discretion to grant compensation if, inter alia, there are sufficient funds, harm can be assessable and compensation is proportional and appropriate. ${ }^{92}$ The ICC could elaborate principles on compensation that refer to domestic available mechanisms at which individual victims may file compensation claims. ${ }^{93}$ Nevertheless, this would likely face non-existent compensation programmes and/or collapsed national systems, in which case the ICC and the TFV should carefully consider whether and to what extent victims' potential access to other sources (the TFV's included) may be necessary or appropriate. ${ }^{94}$

With regard to modalities of collective reparations and as requested by the victims, T.Ch-II in Katanga granted measures that support housing, income-generating activities, education and psychological well-being. ${ }^{95}$ T.Ch-II did not explicitly categorize these reparative measures. However, they arguably are mainly rehabilitation, i.e., medical, psychological care, legal and social services, and to some extent restitution, i.e., restoration of the victim's situation prior to the violation via inter alia return to his/her place of residence/home and previous employment. ${ }^{96}$ Concerning collective symbolic reparations (satisfaction and guarantees of non-repetition), unlike Lubanga, victims in Katanga did not want to receive

\footnotetext{
${ }^{90}$ Bassiouni (n 59) 269.

${ }^{91}$ AFP, 'ICC awards "symbolic" \$250 each to Congo war crimes victims' (24 March 2017) <www.justiceinfo.net/en/component/k2/32603-icc-awards-symbolic-250-each-to-congo-war-crimesvictims.html > accessed 29 April 2017.

${ }^{92}$ UN Reparation Principle 20; Lubanga (n 2) para 226.

${ }^{93}$ David Donat-Cattin, 'Article 75 ' in Otto Triffterer (ed), Commentary on the Rome Statute of the International Criminal Court (2nd edn, C.H.Beck/Nomos/Hart 2008) 13991405.

${ }^{94}$ Ibid.

${ }^{95}$ Katanga (n 1) para 302.

${ }^{96}$ UN Reparation Principles 21 (rehabilitation), 19 (restitution); Lubanga (n 3) paras 35-36, 41-42; Bassiouni (n 59) $268,270$.
} 
them. Victims excluded commemorating events, dissemination of the process, construction of monuments, and search of the disappeared persons because of the socio-cultural context and victims' consideration of these modalities as inapplicable, useless, or potential triggers of revictimization or increase in insecurity. ${ }^{97}$ This demonstrates that certain reparations rendered by international courts are not necessarily or automatically applicable at the ICC.

\section{Implementing the Katanga Reparation Order}

T.Ch-II tasked the TFV to prepare and submit, for the Chamber's approval, a draft plan on implementation of reparations for victims identified by the Chamber, considering appropriate measures to protect the security, psychical/psychological well-being, and privacy of the victims and giving priority (if needed) to vulnerable victims. ${ }^{98}$ The TFV submitted the said draft plan which has yet to be approved. ${ }^{99}$ ICC reparation awards can only be rendered against the convicted. This principle faces and triggers quite difficult practical challenges. Like Lubanga, Katanga was declared judicially indigent, i.e., he currently lacks property or assets for reparation purposes. ${ }^{100}$ Nevertheless, by following the A.Ch's conclusion in Lubanga, ${ }^{101}$ T.Ch-II in Katanga found that indigence of the convicted is not a reason to avoid imposition of liability on him/her for reparation awards. ${ }^{102}$ The principle of liability may be linked to the potential expressivist (vindictive satisfaction and moral denunciation) account of victim redress. ${ }^{103}$ T.Ch-II applied the principle whereby the convicted person's liability must be proportionate to the harm caused and, among others, his/her participation in the crimes for

\footnotetext{
${ }^{97}$ Katanga (n 1) para 301.

${ }^{98}$ Ibid paras 307-311.

${ }^{99}$ Katanga (ICC-01/04-01/07-3751-Red), Draft Implementation Plan (25 July 2017),

${ }^{100}$ Katanga (n 1) para 327.

${ }^{101}$ Lubanga (n 29) paras 102- 105.

${ }^{102}$ Katanga (n 1) paras 242-246.

${ }^{103}$ McCarthy (n 39) 60-63.
} 
which he/she was found guilty. ${ }^{104}$ Thus, Katanga is liable for an amount of 1 million USD as for reparations. ${ }^{105}$

As Katanga cannot immediately fund the reparation award, T.Ch-II recalled that the TFV may decide to complement the amount needed to finance the reparation award rendered by T.Ch-II making use of its 'other resources'. ${ }^{106}$ In conformity with the ICC instruments, ${ }^{107}$ the TFV accepted to proceed accordingly but concerning exclusively collective reparations. ${ }^{108}$ This is related to T.Ch-II's decision to order only the symbolic 250 USD figure as individual compensation. Since the total amount of individual reparations solely constitutes $7 \%$ (74250 USD) of the figure for which Katanga is liable, T.Ch-II recommended the TFV to use part of its 'other resources' to fund those individual awards. ${ }^{109}$ In the end, the TFV followed this recommendation because The Netherlands donated 74250 USD for Katanga individual reparations, and 125750 USD that the TFV decided to use for Katanga collective awards. ${ }^{110}$ Thus, decisive factors are that collective reparation funds come from donations and contributions by state parties, institutions and individuals, and also that these funds so far total 5.5 million EUR as ICC-TFV's reparation preparation reserve for all ICC cases. ${ }^{111}$

However, there is an avenue for prompt involvement of Katanga in reparation implementation. T.Ch-II noted that the convicted can apologize publicly or privately to victims. ${ }^{112}$ Apologies constitute symbolic measures, particularly, satisfaction and should ideally be public. ${ }^{113}$ However, private apologies may be understandable as the convicted is the

\footnotetext{
${ }^{104}$ Katanga (n 1) para 252.

${ }^{105}$ Ibid para 264.

${ }^{106}$ Ibid para 330.

${ }^{107}$ Rule 98(2); TFV Regulation 56.

${ }^{108}$ Katanga (n 1) para 331.

${ }^{109}$ Ibid paras 338-342.

${ }^{110}$ Katanga (n 99) paras 46-49.

${ }^{111}$ Report to the Assembly of States Parties, (ICC-ASP/16/14), 21 August 2017, para 2 .

${ }^{112}$ Katanga (n 1) para 315.

${ }^{113}$ UN Reparation Principle 22(d).
} 
one who has to apologize at the ICC. In any event, Katanga has expressed his willingness to fully assist rehabilitation programmes proposed by the Chamber or the TFV. ${ }^{114}$

Considering the above-mentioned challenges and hurdles to the implementation of the Katanga reparation order, T.Ch-II indicated that reparations or benefits already given to victims by other bodies could be considered so that reparations do not lead to injustices or discrimination. ${ }^{115}$ Additionally, under article $75(6)$ of the ICC Statute which states that 'Nothing in this article shall be interpreted as prejudicing the rights of victims under national or international law', T.Ch-II remarked that the ICC reparation awards do not exonerate States Parties to the ICC Statute from their responsibility to provide reparations under other treaties or national legislation. ${ }^{116}$ Furthermore, under the ICC Statute, States Parties to the ICC Statute are obligated to cooperate with the ICC and are encouraged to facilitate the implementation of reparation awards. ${ }^{117}$ Indeed, the DRC is interested in participating in the implementation of reparation awards in Katanga, ${ }^{118}$ which requires coordination with the TFV. There are some reparations such as memorials or national commemorative days whose implementation demand state actions. Successful implementation of ICC reparation orders certainly requires state cooperation and involvement.

Finally, there is complementarity between international state responsibility and individual criminal liability for facts that constitute both serious human rights violations and international crimes. ${ }^{119}$ Such complementarity is indeed suggested in the ICC Statute, namely, articles 25(4) (determination of criminal liability does not affect establishment of state responsibility) and the previously quoted article 75(6). Dual individual-state responsibility explains the need for redress the harm inflicted on victims at and beyond the ICC. This is

\footnotetext{
${ }^{114}$ Katanga (n 1) para 316.

${ }^{115}$ Ibid para 319.

${ }^{116}$ Ibid para 323.

${ }^{117}$ ICC Statute, Parts IX-X.

${ }^{118}$ Katanga (n 1) para 325.

${ }^{119}$ Antonio Cançado-Trindade, International Law for Humankind-Towards a New Jus Gentium (Brill/Nijhoff 2010) 367-374.
} 
clearly the case when state actors are convicted or, arguably, when these actors are involved. Katanga's rebel group, the FRPI, actually received support from Uganda.

\section{Conclusion}

The Katanga reparation order constitutes an important step towards the consolidation of the emerging practice of the ICC reparation system. It applies the substantive and procedural law of reparations under the ICC legal instruments and ICC case-law as tailored to the particular circumstances in Katanga. It also develops certain areas previously unexplored, including references to external legal sources such as human rights case-law. However, the challenges to implement ICC reparation orders, including the Katanga reparation order, are quite prominent. Thus, it is necessary to complement the ICC reparation system with other restorative justice initiatives, including national reparation programmes and reparation awards ordered by human rights courts against responsible states. Only in this manner would the right of victims of serious human rights abuses to receive prompt and appropriate reparations be satisfied.

Upon T.Ch-II's request, the TFV's draft implementation plan actually proposes for the DRC authorities' consideration and response manners in which the DRC could facilitate the Katanga reparation order implementation, including waiver of school fees, allocation of a rural development centre, and provision of land and construction materials. ${ }^{120}$ Thus, the Katanga reparation order may potentially become a catalyst for actions from states and human rights courts (via state responsibility determination). This reflects the need for 'tripartite'

\footnotetext{
${ }^{120}$ Katanga (n 99) paras 68-72.
} 
reparative complementarity (ICC/states/human rights courts) yet to be implemented in international law. 